\title{
Managing the Obligation to Stay through Employee Involvement, Recognition and AMO Model: A Study amongst Millennial Employees
}

\author{
Roshidi Hassan, Elaina Rose Johar* and Norzanah Mat Nor
}

\begin{abstract}
Manuscript type: Research paper

Research aims: The aim of this paper is to investigate the impact of human resource practices, namely employee involvement and employee recognition, on normative commitments. It also attempts to determine the role of the ability, motivation and opportunity (AMO) model as a mediator in the relationship associated with human resource practices, and normative commitments.

Design/Methodology/Approach: Data were collected across 168 employees, working in small and medium enterprises (SMEs) in Selangor, Malaysia. Structural equation modelling with bootstrapping estimation was used to predict and estimate the relationships.

Research findings: The results indicate that both employee involvement and employee recognition have a significant impact on the normative commitment. This study however, indicates no mediation effect on both of these relationships.
\end{abstract}

\footnotetext{
* Correponding author: Elaina Rose Johar is a Postgraduate Student at the Arshad Ayub Graduate Business School, UiTM Shah Alam, Selangor, Malaysia. Email: ell_r7@yahoo.com.sg Roshidi Hassan is a Professor at the Arshad Ayub Graduate Business School, UiTM Shah Alam, Selangor, Malaysia. Email: roshidih@uitm.edu.my

Norzanah Mat Nor is an Associate Professor at the Arshad Ayub Graduate Business School, UiTM Shah Alam, Selangor, Malaysia. Email: norzanah@uitm.edu.my
}

Acknowledgement: The authors would like to sincerely thank Arshad Ayub Graduate Business School (AAGBS), UiTM Shah Alam for funding this research through the AAGBS research grants.

https://doi.org/10.22452/ajba.vol13no2.4 
Theoretical contribution/Originality: This study seeks to compliment and extend the human resource (HR) practice and organisational commitment literature base by incorporating the AMO model as a mediation variable.

Practitioner/Policy implication: The underlying messages to HR practitioners and also SMEs owners are that employee involvement and employee recognition are amongst the most important HR practices to be employed in the current working environment, which will soon be dominated by the millennials. Organisations should focus on exhibiting a great working environment that involves employees in daily work activities, and promotes recognition programmes that motivates employees' retention rates.

Research limitation: Data were collected through the use of a questionnaire in a designated period of time, and did not permit causal inferences. Moreover, it only focusses on service sectors of SMEs, and therefore the results may not be as generalised as one sought it to be.

Keywords: Employee Involvement, Employee Recognition, Normative Commitment, AMO model

JEL Classification: M12

\section{Introduction}

In this competitive business age, with most organisations engaged in a talent war, the human resources section in an organisation makes an imperative contribution to the success or failure of the organisation. What each employee brings to the organisation is special, and not easily imitated (Subramaniam, Shamsudin \& Ibrahim, 2011). Employees are largely responsible for the implementation and realisation of the organisation's goals and strategies. Employee engagement is one of the critical obstacles for an organisation. The issue of job-hopping amongst Malaysian employees is becoming crucial. Randstad (2019) reported that 21 per cent of employees in Malaysia transitioned to new jobs in 2018, while 38 per cent of them planned to do so in 2019. This issue was reported to be much more significant amongst millennials and Gen-Zs. Considering the fact that these two groups of generations dominate the existing workplace by taking up the middle and senior management positions, it is imperative for organisations to develop a strategy to attract and retain millennials and to prepare their young talents for future leadership roles. Moreover, it is relatively common that there will be a gap between employees' expectations. What the organisation is offering 
as a commitment is a confidence built on the employee's perception of the employer's commitment to them, and returns the employer's good actions through their own thinking and behaviour (Osa \& Amos, 2014).

The importance of gaining commitment from such human assets is not only relevant in large organisations, but also in small and growing organisations, such as small and medium enterprises (SMEs). The SME Master Plan 2012-2020 has identified that the deterioration of performance of Malaysian SMEs is related to the lack of employee commitment due to frequent job-hopping (National SME Development Council, 2012). The chances that employees will remain committed to the organisation depends on their level of productivity, and the commitment of the organisation to support them (Lee \& Chen, 2013; Osa \& Amos, 2014). Taking into account the new cohort of millennial workers who now dominate the workforce, it is important for SMEs to keep up with these changes and manage human assets properly in order to gain and retain their commitment or obligation to stay. Therefore, human resource practices are considered to be an important factor in improving the commitment of employees to the organisation, by recognising that organisational commitment is a pillar of the modern human resource management (HRM) philosophy, as well as the strength that binds HRM practices (Mulolli, Islami, \& Skenderi, 2015).

Using previous reference works, the researchers examined the human resource practices relevant to the organisation's strategic business plan for sustainable performance and competitiveness. This included occupying the "black box" of the HRM-performance relationship, of which the organisational performance was only argued to be positively impacted by HRM practices through the employee's attitudes. In relating to this, human resource experts (Guest, 1997, 2011) have proposed, amongst others, the ability, motivation, opportunity (AMO) model as an option to serve as a mediating mechanism, by which HRM affects the performance. Whilst the AMO model has been studied extensively as a predictor (e.g. Al-Tit, 2020; Li, Jung \& Kim, 2020; Bouwmans, Runhaar, Wesselink \& Mulder, 2019) to employee performance, there is still a dearth of research that looks into the AMO model as an intervening variable in the HR-performance relationship, especially in a Malaysian context.

This study therefore fills the gap by incorporating the AMO model as a mediating variable between employee recognition and normative commitment; it also addresses employee involvement and normative commitment. It focusses on millennial employees working in SMEs, as 
this group of individuals are found to be commonly hopping from one job to another. The rest of this paper is organised as follows. Section 2 reviews previous literature on the underpinning theory and hypotheses development. Section 3 explains the research method, while Section 4 reports on the analysis administered for the associated gathered data. Section 5 discusses the findings and brings the chapter to a conclusion.

\section{Literature Review and Hypotheses Development}

This study is based on the social exchange theory (SET). Blau (1964) introduced SET as an appropriate framework to link perceptions, attitudes and performances. This theory asserts that the resultant outcome of one's behaviour depends on the responsive behaviour by others within the exchange relationship. As human resource practices indicate to employees what the organisation has to offer, employees will at the same time demonstrate an act of reciprocity. They will feel obligated to react with positive attitude and behaviour. Subsequently, when the organisation meets the needs of employees and meets their expectations at the workplace, they will feel appreciated, and a factor called the reciprocal norm will emerge. These employees will reciprocate with a sense of duty and respond with continued high performance (Wayne, Shore, Bommer, \& Tetrick, 2002; Saks, 2006; Wongboonsin et al., 2018). On the contrary, individuals may choose to leave existing relationships, or social exchanges, if the relationship outcomes are lower than expected. In other words, it means that employees leave the organisation or are not committed, unless they see any benefits or reciprocity of their actions in the relationship with the employer. Based on this theory, this study incorporates human resource practices, which are proxied by employee recognition, and employee involvement. These human resource practices are expected to lead to normative commitments through the AMO model. Subsequent sections provide detailed discussion on these relationships.

\subsection{Human Resource Practices and Normative Commitment}

Scholars and practitioners have both acknowledged the role of HRM in enabling the company to remain competitive. Noe, Hollenbeck, Gerhart and Wright (2010) defined HRM as a philosophy, policy, system and practice of employee behaviour, attitudes and performance. It was only recently that the organisation realised the possible role of HRM in 
increasing organisational performance. In the past, organisations often overlooked the contribution of HRM towards organisational successes (Zakaria, Zainal, \& Nasurdin, 2011).

In this study, we believe that committed employees help achieve organisational goals. Employee commitment refers to association with organisational goals, interests in working for the benefit of the organisation, and the willingness to remain with the organisation (Mowday, Steers, \& Porter, 1979). In particular, the sense of obligation to continue employment is referred to as a normative commitment (Meyer \& Allen, 1991). Employees with a high level of normative commitment (NC) feel that they should remain with the organisation. Past studies have shown that there is a correlation between sound HR practices, a sense of duty, and a return to favour, as demonstrated by a substantive commitment. In reality, this responsibility element is nothing but a normative commitment, which plays a key role in establishing a connection between employees and their organisation (Bergman, 2006). The relationship between employees and their organisation would make them more loyal and want to remain in the organisation that appreciates them for much longer.

From previous literature work, it was noticed that there are diverse practices proposed by many of the previous HRM scholars, as there is no agreement on what HRM practices should include. In particular, the number of practices ought to be maintained as long as the organisation is aware of the needs and requirements of employees, in order to assist in the achievement of the specific organisational objectives. For the purpose of this study, employee involvement and employee recognition have been chosen as part of the human resource practices. Increased commitment and improved autonomy space will be achieved as a result of the ownership and responsibility of employee's involvement. On the other hand, employee recognition was chosen, because past studies have shown that recognition as a non-monetary reward has a significant relationship with employee commitment, and increases motivation amongst employees compared to monetary rewards, such as remuneration. Moreover, it is a good step to launch an investigation into the role of both involvement and recognition, especially in the current working environment inhabited by the new generation or cohort.

\subsubsection{Employee Involvement and Normative Commitment}

Employee involvement involves human capacity, responsibility and ownership, and is important to the organisation, as it ensures that these 
visions and values are achieved (Amah \& Ahiauzu, 2013). It is therefore found that employee involvement has a positive impact on productivity and dedication, when authority is provided to employees in terms of their daily work, and when employees are kept in the loop and allowed to influence final decisions (Adham, 2011). Past studies have revealed that there exists a significant relationship between employee involvement and normative commitments (Chelliah, Sundarapandiyan, \& Vinoth, 2015; Zopiatis, Constanti, \& Theocharous, 2014). Involvement in decision-making does not, however, lead to commitment of knowledge workers (Giauque, Resenterra, \& Siggen, 2010). Zopiatis et al. (2014) examined the relationships between work involvement, and affective, and normative commitments. The suggestion is to instigate policies and practices such as informational sharing, and decisionmaking, which empowers and can attract the employee's mentally and emotionally, so as to enable organisations to be aware of employee commitments. Employees will therefore feel a sense of belonging and believe that they have an obligation to stay and continue to work. As a result, individuals who are highly involved in work have a high level of organisational commitment, and are less likely to resign from their jobs. Recent studies by Johar, Nor, Hassan and Musa (2019) on HR practices, which included employee involvement on normative commitment, specifically showed that employee commitment has a significant positive relationship with normative commitments. The findings clearly showed that when employees are given the empowerment and chance to be involved in the decision making, it will help to boost the motivation, sense of responsibility and feeling of satisfaction when their voices are heard. It is thus hypothesised that:

$\mathrm{H}_{1}$ : Employee involvement is positively related to normative commitments.

\subsubsection{Employee Recognition and Normative Commitment}

Recognition has been recognised as an integral part of psychologically healthy workplaces, and has been widely accepted as a critical part of a successful HRM model (Cannon, 2015; Grawitch, Gottschalk, \& Munz, 2006). In addition, employees recognise non-monetary recognition efforts as a result of their attention and organisational support for the creation of a large work environment within the organisation (Paré \& Tremblay, 2000). It is therefore important for organisations to recognise 
that it is necessary for workers to obtain recognition and gratitude, and not just work for the monetary benefits, which will ensure the dedication of employees (Bhatnagar, 2014). A number of previous studies have therefore looked at the link between employee recognition and normative commitments (Ghosh, Rai, Chauhan, Baranwal, \& Srivastava, 2016; Islam, Khan, Ahmad \& Ahmed, 2013). The findings from Ghosh et al. (2016) carried in the context of private banks showed that employees developed strong normative commitments or an obligation to stay when they received appropriate organisational benefits. The rewards and recognition schemes must therefore be designed so that employees are valued for rewarding jobs. Moreover, Prabusankar (2015) found that reward, recognition, skill development and information sharing were based on the positive and significant impact it has on organisational commitments for small-scaled industries in the Coimbatore District, India. Based on the profile of the respondents, the majority of them were male, and were classified as employees of Gen Y. In order to achieve the commitment of this young cohort of workers, organisations, especially small and medium sized industries, or SMEs, should consider recognition programs and practices. Therefore, it is hypothesised that:

$\mathrm{H}_{2}$ : Employee recognition is positively related to normative commitment.

\subsection{The AMO Model as Mediator}

Earlier studies looked at the "black box" of the relationship between HRM and performance and well-known variables in the AMO model, which included three components that enhanced employee performance: individual ability (A), motivation (M) and the opportunity to participate (O) (Appelbaum, Bailey, Berg, \& Kalleberg, 2000). In particular, the AMO model provides a comprehensive description of how HR practices can influence corporate performance through the identification, motivation and participation of employees (e.g. use of attitude investigations) (Obeidat, Mitchell, \& Bray, 2016). This model was considered separately by scholars across three different perspectives: multiplicative, summative and combinative (Marin-Garcia \& Tomas, 2016). They have not yet reached an agreement on which of these perspectives better explain the interaction between capacity, motivation and the dimension of an opportunity. Indeed, the AMO dimensions may be combined differently depending on the levels of analysis (Kim, Pathak, \& Werner, 2015). 
Some scholars considered that performance was best defined by an additive model (Marin-Garcia \& Tomas, 2016). In this way, the level of performance could increase by independently promoting any AMO dimension, and lower levels in one or even two dimensions could be counterweighed for by higher levels in the others (Kim et al., 2015). In addition, other authors proposed that each dimension of the AMO model should be aimed at different objectives, and therefore it could be possible to find organisations in which only ability, motivation or opportunities-enhancing practices are taken into account (Kroon, Van De Voorde, \& Timmers, 2013).

On another note, some authors pointed out that AMO is a multiplicative model. For example, the abilities, motivation and opportunities must all be present (at least to some degree), and the lack of any of them means that performance becomes unattainable. Some scholars argued that there is a lack of research to confirm the multiplicative factor (Marin-Garcia \& Tomas, 2016). A research was piloted by Obeidat, Bray and Mitchell (2010) to offer an empirical verification of the AMO model. The authors argued that the three-factor model was better than the one or two-factor model to explain the link between human resource practice dimensions and performance indicators. This hypothesis was validated in the study to show an empirical verification of the multiplicative model. Nevertheless, as suggested by Almutawa, Muenjohn and Zhang (2016), much more research is needed to explore the mechanism by which the AMO model can be implemented in order to achieve its intended objectives. Furthermore, some authors maintained that the exact relationship between the three dimensions of the AMO has so far remained unknown (Knies \& Leisink, 2014). Likewise, other authors pointed out that either the model had never been fully empirically tested, or the three dimensions had only been independently empirically validated (Demortier, Delobbe, \& El Akremi, 2014). As there has been no agreement yet on the best interaction between the AMO dimensions, this study employs the second-order construct for the AMO model to provide a much more abstract dimension, instead of using unidimensional construct, or a single dimension.

\subsubsection{AMO Model and Normative Commitment}

Accordingly, people perform best when they can do a job (abilities), and they will do a job (motivation) which is complimented by their work environment which offers the necessary support and means of 
expression (opportunity) (Boxall \& Purcell, 2011). Hence, to better understand the model, more empirical research can be linked to the search for new results. According to the AMO model, discretionary effort will positively affect the organisational performance, and advanced research can also be devoted to the duplication of studies with positive results within different contexts, in order to attempt to unlock the socalled "black box" of HRM (Marin-Garcia \& Tomas, 2016). Therefore, previous researches have explored the link that connects the relationship between HR practices and commitment. Guest (1997 \& 2011) suggested the AMO model served as a mediating mechanism, through which the HRM affected the performance, as limited empirical efforts have been identified to explore this mediating effect (Almutawa et al., 2016; Knies \& Leisink, 2014). It is therefore assumed that:

$\mathrm{H}_{3}$ : The AMO model is positively related to the normative commitment.

$\mathrm{H}_{4}$ : Employee involvement is positively related to the AMO model.

$\mathrm{H}_{5}$ : Employee recognition is positively related to the AMO model.

$\mathrm{H}_{6}$ : The AMO model mediates the relationship between employee involvement and normative commitment.

$\mathrm{H}_{7}$ : The AMO model mediates the relationship between employee recognition and normative commitment.

Based on the previous literature and hypotheses development, the following model was developed.

$\mathrm{H}_{1}$

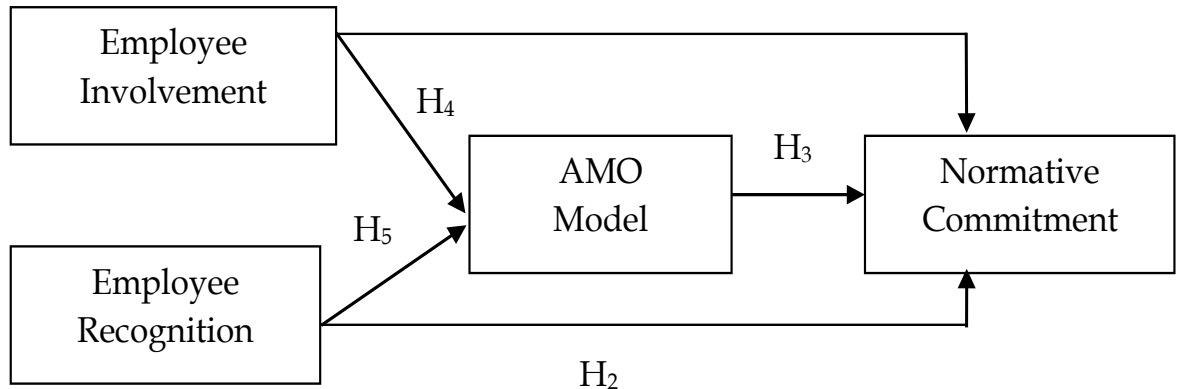

Figure 1: Research Framework 


\section{Research Methodology}

The measurement items used for the questionnaire were adapted from previous literature work, as shown in the Appendix. Thirteen items used to measure the employee involvement were adapted from Adham (2011), while five items were taken from Appelbaum and Kamal (2000) to measure employee recognition. To measure the AMO model we further adapted items from Guay, Vallerand and Blanchard (2000), Rizzo, House and Lirtzman (1970), and Schyns and von Collani (2002). Six items were adapted from Meyer and Allen (1991) as proxies for normative commitments. A 7-point Likert-type scale, ranging from 1 (strongly disagreed) to 7 (strongly agreed) were used to measure all the items in the questionnaire.

In general, SMEs are the largest number of establishments in many countries worldwide. Without exception, these SMEs account for 98.5 per cent of the total number of establishments in Malaysia (National SME Development Council, 2017). According to the Economic Census 2016 (Department of Statistics Malaysia, 2016), the service industry represented 89.2 per cent of the total number of SMEs in Malaysia and Selangor. Despite being the largest sector, the service sector was chosen because previous studies have shown that research in the service sector firms is scarce (Jones, Kalmi, \& Kauhanen, 2010; Hooi \& Ngui, 2014; Shin \& Konrad, 2017). The SME Masterplan (2012-2020) also identified that the performance of SMEs had deteriorated due to the problem of employee commitment (National SME Development Council, 2012).

The sampling framework for this research study consisted of SMEs in Selangor. The lists of SMEs that received and won the Enterprise 50 (E50) Award from 1998 to 2017 were obtained from the SME Corporation of Malaysia and were used as the sampling frame. The reason is that the award honoured the top 50 SMEs in the country, in recognition of their achievements in terms of financial capability, operations and management skills. The winners have therefore established their management not only as successful enterprises, but also as productive national assets, and global players (SME Corporation Malaysia, 2018). Thus, the list consisted of 100 service sector SMEs in Selangor, and, as a result, there were 3,000 employees in total, each of whom had at least 30 employees based on the definition of SMEs (National SME Development Council, 2017).

The respondents for this research study consisted of millennial employees in the service sector for SMEs in Selangor. Based on the 
$\mathrm{G}^{*}$ Power analysis, a minimum sample size of 107 is required to produce a power of 0.95 for the medium effect size model (Hair, Black, Babin, $\&$ Anderson, 2013). However, the sample size was increased to 300 in order to reduce the risk of non-response bias that could result from the refusal of the sample members to respond, unable to respond, or be inaccessible to the researcher (Merkle, 2008; Williams, 1978; Yu \& Cooper, 1983). The HR departments of the SMEs in the sampling lists were contacted to obtain permission for the questionnaire distribution. Of the 300 distributed questionnaires, only 168 responses were obtained, resulting in a response rate of 56 per cent. Table 1 depicts the respondents' profiles. Accordingly, 63 per cent of the total respondents were female, the majority of whom were Malay $(83 \%)$. Also, most respondents held executive positions (57\%) with two to five years experience $(55 \%)$ and earned a monthly income between RM1,000 and RM3,000 (59\%).

\section{Data Analysis}

In this study, the partial least square (PLS) method was used to test the hypotheses developed. PLS is a second-generation multivariate technique that can simultaneously evaluate the measurement model (the relationship between constructs and their corresponding indicators), and the structural model with the aim of minimising the error variance of the data (Hair, Hult, Ringle, \& Sarstedt, 2017). The PLS bootstrapping method was used to determine the level of significance for loads, weights and path coefficients. In addition, the common method variance is needed to be evaluated, since all data was collected through selfreported questionnaires, and both the predictor and criterion variables were collected from the same source (Podsakoff, MacKenzie, Lee, \& Podsakoff, 2003). Full estimates of collinearity were made to detect this problem. According to Kock and Lynn (2012), a block was developed and all the latent variables in the model were included as predictors pointing to a single criterion, a dummy variable. Since this test enabled the identification of collinearity among all variables in the model, regardless of where they were placed in the model, it was considered to be a more rigorous and conservative test of collinearity. Specific latent variables referred to different constructs, whether they were in the same block or not in the SEM model. In this analysis, complete collinearity estimates (Table 2) showed that the variance inflation factor (VIF) for all variables were less than 3.3, indicating that the common bias of the process was not a concern in this study. 
Table 1: Respondents' Profiles

\begin{tabular}{llrr}
\hline Characteristic & Group & Frequency & Percentage \\
\hline Gender & Female & 106 & 63.1 \\
Race & Male & 62 & 36.9 \\
& Malay & 140 & 83.3 \\
& Chinese & 22 & 13.1 \\
& Indian & 3 & 1.8 \\
Age & Others & 3 & 1.8 \\
& Below 25 & 43 & 25.6 \\
Academic Qualification & 26-35 & 125 & 74.4 \\
& SPM & 11 & 6.5 \\
& Diploma & 32 & 19.0 \\
& Bachelor Degree & 108 & 64.3 \\
& Master Degree & 14 & 8.3 \\
& PhD & 2 & 1.2 \\
Monthly Income (RM) & Others & 1 & 1 \\
& Less than 1,000 & 2 & 1.2 \\
& 1,000-3,000 & 99 & 58.9 \\
& 3001-5,000 & 51 & 30.4 \\
Level of Position & 5001-7,000 & 14 & 8.3 \\
& More than 7,000 & 2 & 1.2 \\
& Non Executive & 31 & 18.5 \\
& Executive & 96 & 57.1 \\
& Assistant Manager & 9 & 5.4 \\
& Manager & 17 & 10.1 \\
& General Manager & 1 & 0.6 \\
& Others & 14 & 8.3 \\
& Less than 1 year & 44 & 26.2 \\
& 2-5 years & 92 & 54.8 \\
& 6-10 years & 30 & 17.9 \\
& 11-15 years & 2 & 1.2 \\
\hline
\end{tabular}

Table 2: Full Collinearity Estimates

\begin{tabular}{ccccc}
\hline & AMO & $\begin{array}{c}\text { Normative } \\
\text { Commitment }\end{array}$ & $\begin{array}{c}\text { Employee } \\
\text { Involvement }\end{array}$ & $\begin{array}{c}\text { Employee } \\
\text { Recognition }\end{array}$ \\
\hline VIF & 1.995 & 2.048 & 2.260 & 2.017 \\
\hline
\end{tabular}

Note: The VIFs shown are for all of the latent variables; a "dummy" latent variable criterion was used. VIFs equal to or greater than 3.3 suggest collinearity. 


\subsection{Measurement Model Evaluation}

Prior to the structural model and hypotheses evaluation, a measurement model analysis was conducted. The convergent validity and discriminant validity were evaluated in this phase (Hair et al., 2017). To evaluate the convergent validity, we inspected the factor loadings, average variance extracted (AVE) and composite reliability (CR). Threshold values of 0.6 for factor loadings, 0.5 for AVE and 0.7 for $\mathrm{CR}$ were used as indicators. For factor loadings however, Hair et al. (2017) indicated that an outer loading of between 0.4 and 0.7 should be considered, unless its removal would increase the average variance extracted (AVE) threshold. As depicted in Table 3, the results of the measurement model surpassed the prescribed values, suggesting an appropriate convergence validity. In the case of the AMO model, which was conceptualised as a second-order construct, we adopted a repeat indicator approach as proposed in the PLS literature (Hair, Sarstedt, Ringle, \& Gudergan, 2018). In order to evaluate the discriminant validity, we used the Heterotrait-monotrait correlation ratio (HTMT) as an indicator, in line with the work by Henseler, Ringle and Sarstedt (2015). As reported in Table 4, all the HTMT values for all methods obtained similar results under the conservative threshold of 0.85 (Franke \& Sarstedt, 2019; Kline, 2016; Voorhees, Brady, Calantone \& Ramirez, 2016), illustrating the fact that the measurement model used conformed to the discriminant validity. The bootstrapping procedure was carried out with 5,000 samples. The findings showed that none of the HTMT confidence intervals included a value of 1 , indicating that all the HTMT values were significantly different from 1 .

\subsection{Structural Equation Modelling - Partial Least Square (SEM-PLS)}

The assessment of the structural model involved examining the predictive capabilities of the model, and the relationship between the constructs in the path model. It included the assessment of collinearity (variance inflation factor, VIF), the assessment of the coefficient of determination $\left(\mathrm{R}^{2}\right)$ and the size of the effect $\left(\mathrm{f}^{2}\right)$ (Hair et al., 2017). As shown in Table 5, the VIF values were below the threshold of 5 (Hair, Ringle, \& Sarstedt, 2011), suggesting that collinearity amongst the predictor construct was not a critical issue in this structural model. Subsequently, the $\mathrm{R}^{2}$ was evaluated. The rule of thumb for $\mathrm{R}^{2}$ values of $0.75,0.50$, or 0.25 can be respectively described as substantial, moderate, 
Table 3: Convergent Validity

\begin{tabular}{|c|c|c|c|c|c|}
\hline $\begin{array}{l}\text { First order } \\
\text { construct }\end{array}$ & Item & Loading & $\begin{array}{l}\text { Second order } \\
\text { construct }\end{array}$ & AVE & CR \\
\hline $\mathrm{NC}$ & $\begin{array}{l}\text { NC2 } \\
\text { NC3 } \\
\text { NC4 } \\
\text { NC5 } \\
\text { NC6 }\end{array}$ & $\begin{array}{l}0.688 \\
0.818 \\
0.865 \\
0.881 \\
0.791\end{array}$ & & 0.658 & 0.905 \\
\hline $\begin{array}{l}\text { Employee } \\
\text { involvement }\end{array}$ & $\begin{array}{l}\text { EI1 } \\
\text { EI2 } \\
\text { EI3 } \\
\text { EI4 } \\
\text { EI5 } \\
\text { EI6 } \\
\text { EI7 } \\
\text { EI8 } \\
\text { EI9 } \\
\text { EI10 } \\
\text { EI11 } \\
\text { EI12 } \\
\text { EI13 }\end{array}$ & $\begin{array}{l}0.571 \\
0.571 \\
0.686 \\
0.528 \\
0.548 \\
0.783 \\
0.754 \\
0.803 \\
0.69 \\
0.796 \\
0.838 \\
0.824 \\
0.758\end{array}$ & & 0.507 & 0.929 \\
\hline $\begin{array}{l}\text { Employee } \\
\text { recognition }\end{array}$ & $\begin{array}{l}\text { RE1 } \\
\text { RE3 } \\
\text { RRE2 } \\
\text { RRE5 }\end{array}$ & $\begin{array}{l}0.956 \\
0.945 \\
0.454 \\
0.349\end{array}$ & & 0.534 & 0.797 \\
\hline Ability & $\begin{array}{l}\text { A1 } \\
\text { A2 } \\
\text { A3 } \\
\text { A4 } \\
\text { A5 } \\
\text { A6 } \\
\text { A7 }\end{array}$ & $\begin{array}{l}0.567 \\
0.809 \\
0.831 \\
0.837 \\
0.868 \\
0.859 \\
0.818\end{array}$ & & 0.647 & 0.927 \\
\hline Motivation & $\begin{array}{l}\text { M1 } \\
\text { M2 } \\
\text { M4 } \\
\text { M5 } \\
\text { M7 }\end{array}$ & $\begin{array}{l}0.845 \\
0.736 \\
0.743 \\
0.841 \\
0.807\end{array}$ & & 0.537 & 0.864 \\
\hline Opportunity & $\begin{array}{l}\mathrm{O} 1 \\
\mathrm{O} 2 \\
\mathrm{O} 3 \\
\mathrm{O} 4 \\
\mathrm{O} 6\end{array}$ & $\begin{array}{l}0.626 \\
0.651 \\
0.822 \\
0.838 \\
0.655\end{array}$ & AMO model & $\begin{array}{l}0.525 \\
0.87\end{array}$ & $\begin{array}{l}0.845 \\
0.69\end{array}$ \\
\hline
\end{tabular}

Note: $\mathrm{AVE}=$ average variance extracted, $\mathrm{CR}=$ composite reliability. 
Table 4: Discriminant Validity

\begin{tabular}{lcccc}
\hline & AMO & $\begin{array}{c}\text { Employee } \\
\text { Involvement }\end{array}$ & $\begin{array}{c}\text { Employee } \\
\text { Recognition }\end{array}$ & NC \\
\hline AMO & & & \\
Employee & 0.75 & & \\
Involvement & $(0.68 ; 0.804)$ & & \\
Employee & 0.511 & 0.518 & \\
Recognition & $(0.405 ; 0.569)$ & $(0.388 ; 0.563)$ & 0.632 \\
NC & 0.601 & 0.644 & $(0.524 ; 0.707)$ \\
\hline
\end{tabular}

Note: The values in brackets represent the $95 \%$ bias-corrected and accelerated confidence interval of the HTMT values obtained by running the bootstrapping routine with 5,000 samples in SmartPLS.

Table 5: Coefficient of Determination $\left(\mathrm{R}^{2}\right)$, Collinearity Assessment (VIF) and Effect size $\left(\mathrm{f}^{2}\right)$

\begin{tabular}{|c|c|c|c|c|c|}
\hline & \multirow{2}{*}{$\mathrm{R}^{2}$} & \multicolumn{2}{|c|}{ VIF } & \multicolumn{2}{|c|}{$\mathrm{f}^{2}$} \\
\hline & & $\mathrm{AMO}$ & $\mathrm{NC}$ & $\mathrm{AMO}$ & $\mathrm{NC}$ \\
\hline $\mathrm{NC}$ & 0.504 & - & - & - & - \\
\hline $\mathrm{AMO}$ & 0.5 & - & 2.0 & - & 0.019 \\
\hline Employee Involvement & - & 1.491 & 2.135 & 0.432 & 0.058 \\
\hline Employee Recognition & - & 1.491 & 1.577 & 0.058 & 0.242 \\
\hline
\end{tabular}

Note: NC is normative commitment and AMO is ability, motivation and opportunity model.

or weak (Hair et al., 2011; Henseler, Ringle, \& Sinkovics, 2009). $\mathrm{R}^{2}$ for both the AMO and normative commitment was therefore considered to be moderate with values of 0.5 for the AMO model, and 0.504 for the normative commitment. The $\mathrm{f}^{2}$ refers to the change in $\mathrm{R}^{2}$ when the specified exogenous construct (employee involvement and employee recognition) is omitted from the model (Hair et al., 2017). The $\mathrm{f}^{2}$ values of $0.02,0.15$ and 0.35 were small, medium and large, respectively (Cohen, 1988). Table 5 shows that the employee involvement depicted a large effect size with a value of 0.432 on the AMO, and a small effect size of 0.058 on the normative commitment, while the employee recognition showed a small effect size of 0.058 and a medium effect size of 0.242 on the AMO model and normative commitment, respectively. 


\subsection{Findings of the Structural Model Path Coefficient}

In order to estimate the structural model, a bootstrapping procedure with 5,000 samples was run to generate $t$-values and $p$-values. The first step was to observe factors related to the normative commitment, such as employee involvement, employee recognition and the AMO model. Employee involvement and employee recognition had a direct relationship with normative commitment (Table 6), since the t-value was higher than the critical value, 1.645, at the 5\% significance level (one-tailed test). The p-value of this relationship was lower than the 0.05 significance level, and the confidence interval for the relationship also has a similar result, which did not include zero. Hypotheses $\mathrm{H}_{1}$ and $\mathrm{H}_{2}$ were therefore supported. In addition, the AMO model showed an insignificant direct relationship to the normative commitment. The $\mathrm{H}_{3}$ hypothesis was therefore not supported. The research study also looked at the predictors of the AMO model as shown in Table 7, which were employee involvement and employee recognition. Both predictors had

Table 6: Significance Testing Results of the Structural Model Path Coefficients on the Employee Commitment

\begin{tabular}{lccccc}
\hline Paths & $\begin{array}{c}\text { Path } \\
\text { Coefficients }\end{array}$ & $\begin{array}{c}\mathrm{t}- \\
\text { values }\end{array}$ & $\begin{array}{c}\mathrm{p} \\
\text { values }\end{array}$ & $\begin{array}{c}\text { 95\% Confidence } \\
\text { Interval }\end{array}$ & $\begin{array}{c}\text { Significance } \\
(\mathrm{p}<0.05)\end{array}$ \\
\hline $\mathrm{AMO} \rightarrow \mathrm{NC}$ & 0.137 & 1.494 & 0.136 & $(0.006 ; 0.309)$ & No \\
$\mathrm{EI} \rightarrow \mathrm{NC}$ & 0.248 & 2.735 & 0.006 & $(0.083 ; 0.381)$ & Yes \\
$\mathrm{ER} \rightarrow \mathrm{NC}$ & 0.435 & 6.937 & 0 & $(0.32 ; 0.53)$ & Yes \\
\hline
\end{tabular}

Note: EI is employee involvement, ER is employee recognition, NC is normative commitment and AMO is ability, motivation and opportunity model. The critical values for one-tailed test are 1.645 (significance level=5\%).

Table 7: Significance Testing Result of Structural Model Path Coefficient on the AMO model

\begin{tabular}{lccccc}
\hline Paths & $\begin{array}{c}\text { Path } \\
\text { Coefficients }\end{array}$ & $\begin{array}{c}\mathrm{t}- \\
\text { values }\end{array}$ & $\begin{array}{c}\mathrm{p} \\
\text { values }\end{array}$ & $\begin{array}{c}\text { 95\% Confidence } \\
\text { Interval }\end{array}$ & $\begin{array}{c}\text { Significance } \\
(\mathrm{p}<0.05)\end{array}$ \\
\hline $\mathrm{EI} \rightarrow \mathrm{AMO}$ & 0.567 & 11.546 & 0 & $(0.492 ; 0.649)$ & Yes \\
$\mathrm{ER} \rightarrow \mathrm{AMO}$ & 0.207 & 3.889 & 0 & $(0.114 ; 0.292)$ & Yes \\
\hline
\end{tabular}

Note: EI is employee involvement and ER is employee recognition. The critical values for one-tailed test are 1.645 (significance level=5\%). 
a significant positive relationship on the AMO model. The results indicated that the hypotheses $\mathrm{H}_{4}$ and $\mathrm{H}_{5}$ were supported.

\subsection{Findings of the Mediation Effect}

Testing the mediation type in the model required a series of analyses and procedures. The first stage in assessing the mediation effect was to address the significance of the indirect effect. As such, we assessed the importance of employee involvement and employee recognition toward employee commitment through the mediator variable, the AMO model. If the indirect effect was not significant, further analysis could be carried out to determine if it is direct-only non-mediation, or no-effect nonmediation. Furthermore, if the indirect effect was significant, we had to determine whether the direct effect was significant in order to classify the construct as indirect only (full mediation), complementary mediation (partial mediation) or competitive mediation (partial mediation). If the direct effect shows that it is not significant, the research study can conclude that the indirect-only mediation had occurred. If the direct effect shows that it is significant, the research study can distinguish between complementary, and competitive mediation. Complementary mediation describes a situation in which the direct and indirect effects point in the same way, and the competitive mediation explains the vice versa of complementary mediation (Hair et al., 2017). As depicted in Table 8 , there was no mediation effect of the AMO model between employee involvement and employee recognition with normative commitment reported, since the $\mathrm{t}$-value was lower than the critical value of 1.96 (twotailed test), and the p-value was greater than the $5 \%$ significance level, respectively. Hypotheses $\mathrm{H}_{6}$ and $\mathrm{H}_{7}$ were therefore not supported. The total effect of employee involvement on normative commitment was 0.326 , and employee recognition on normative commitment was 0.464 for both indirect and direct effects, as shown in Table 8.

\section{Discussion}

The goal of this study is to analyse the relationship between HR practices (employee involvement and employee recognition) and the normative commitment of millennial employees across SMEs in Selangor, and to explore the role of the AMO model as a mediating variable between relationships. The finding shows that employee involvement is positively related with normative commitment (Chelliah et 
Roshidi Hassan, Elaina Rose Johar, and Norzanah Mat Nor

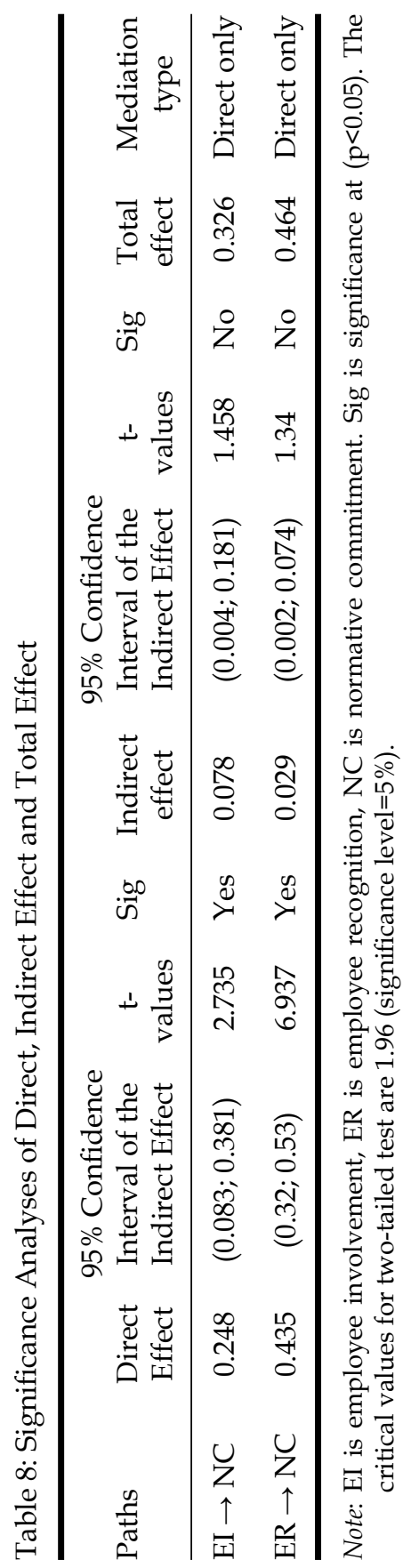


al., 2015; Johar et al., 2019; Zopiatis et al., 2014). Remarkably, millennials become more engage when an organisation give them the opportunity to engage and, in particular, to participate in decision-making, and to maintain confidence in their daily work. When this happens, employees feel that their existence has been cherished, that their voices has been heard, and that there is a room for them to unleash their potential. This feeling of involvement in the organisation and, more specifically, their work, made them feel the need to remain committed and to reciprocate with good results, as a means of reflecting upon the opportunities that the organisation has given them.

Likewise, employee recognition also contributes significantly to normative commitments. This finding is in line with past studies (Ghosh et al., 2016; Prabusankar, 2015). In fact, employee recognition is widely accepted as a critical part of effective HRM (Cannon, 2015). The recognition received by employees make them feel valued and appreciated. This boosts their motivation and instils a sense of obligation to stay longer in the organisation. This shows that proper recognition, in particular, an informal recognition between colleagues or the superiorsubordinate, can strengthen the relationship between them. A simple word of 'thank you' or 'well done' can lead to a sense of belonging to the organisation, and employees will eventually reciprocate it through commitment. Surprisingly, the AMO model has an insignificant direct relationship with normative commitment. Notably, millennial employees are well equipped with skills and abilities, and therefore HR practices alone (employee involvement and employee recognition) have been good enough to obtain a normative commitment from millennials. Conversely, this insignificant finding is opposed to previous studies which found AMO to have a relationship with organisation commitment and performance (Almutawa et al., 2016; Bos-Nehles, Van Riemsdijk, \& Kees Looise, 2013; Kim et al., 2015; Knies \& Leisink, 2014; Nor \& Abdullah, 2020).

Secondly, the results indicate that both employee involvement and employee recognition have a significant positive relationship with the AMO model. This aligns with previous literature work (Boxall \& Purcell, 2011; Demortier et al., 2014; Jiang et al., 2012). Obviously, when the organisation provides a supportive working environment by actively involving employees in management activities, employees are well-recognised for their efforts and functioned well at work. Therefore, employees are keen to develop their skills and capabilities. Workers can feel much more appreciated and respected, and thus lead employees to 
perform well when they have the ability to do a job (A), they feel a lot of motivation to do a job (M), and their work environment provides the necessary support and avenues of expression, $(\mathrm{O})$. As a result, sound HR procedures will lead to an increase in the AMO of the employees. Employee involvement can especially increase the AMO of employees, which includes decision-making, sharing of knowledge, across the board communication, and job enrichment opportunities (Appelbaum et al., 2000; Schimansky, 2014). Besides that, employee recognition also shows a significant relationship with the AMO model. Employee involvement and recognition are linked together, since employee recognition programs may backfire if organisations do not involve employees in developing processes (Cannon, 2015). It clearly shows that employees will disclose their AMO when they feel that the organisations recognises them.

Thirdly, the mediating role of the AMO model between the involvement of employees, and the recognition of employees with normative commitment has not been established. The AMO model does not mediate the relationship, which is opposed to the previous study by Almutawa et al. (2016). The authors found that the similar role of the AMO model existed, so as to having a partial mediation in the relationship between the HR system and employee commitment. Nonetheless, both the involvement of the employees and the recognition of employees have only a significant direct relationship with the normative commitment. This further proves that this study model does not require $\mathrm{AMO}$ as an intervention variable that links the relationship between employee involvement and employee recognition with normative commitment. Perhaps, the AMO model might mediate the relationship with other types of employee commitment, such as affective commitment or continuance commitment. Moreover, this result suggests that millennials are currently well equipped with the appropriate skills, and that SMEs are doing well in terms of involving employees, and that they are well aware of them. In fact, SMEs should place more emphasis on HR practices that really meet the needs and wishes of millennia in this context.

\section{Conclusions and Implications}

This study provides an insight of what drives millennial employees to stay longer in a specific organisation, with a special focus on the normative commitment, or obligation to stay. It highlights the role of HR practices as a dynamic key metric in promoting commitment 
of employees. The results of this study suggests that SMEs need to emphasise the involvement of employees, keep them in the loop for any decision-making processes, and empower them on their day-to-day work routines, in order to encourage them to stay in the organisation. Equally, good recognition practices could also motivate employees to feel obliged to do so. This shows that SMEs should not only focus on offering monetary rewards, but also emphasise on other employee recognition programs that could make the employees feel valued and appreciated. Securing commitment of employees is important, as this helps SMEs establish a stable organisation.

The findings of this study also provide an empirical evidence on the applicability of the social exchange theory, in the context of human resources. It extended the existing literature by concentrating on the millennial context. This generation forms the largest population of workers around the globe. Besides being tech-savvy, they are influenced greatly by technology, and they are expected to view the world, including their employment, very differently. Although this study is not able to establish the role of AMO as a mediator, this result should be interpreted cautiously, as it only focuses on the SMEs in Malaysia. This suggests that future studies to expand this research framework across large scale organisations in different countries is necessary. Longitudinal research would also help to supplement this work, as it provides a clearer picture of the associated causal inferences, and allows for the consideration of improvements in overtime with regard to the implementation of HR practices, as well as the commitment of employees. In addition, the difference in the background, and the experiences of the respondents, may lead to biases in the questionnaires provided, as they may respond to them based on their own perceptions. The widening of the sample size can therefore improve the variety of perceptions included in the study. It is also believed that such research would offer new, practical perspectives to the body of knowledge, as well as provide better visions for management. It would also benefit practitioners who are tasked with managing the seamless and complex characteristics of millennial workers, especially in SMEs.

\section{References}

Adham, A. (2011). Employee involvement and its impact on job satisfaction and organisational commitment (Evidence from the 2011 Workplace Employment Relations study). International Journal of Sciences: Basic and Applied Research, 18(2), 368-400. 
Al-Tit, A.A. (2020). The impact of AMO-HR systems on proactive employee behavior: The mediating contribution of leader-member and team-member exchange. International Journal of Engineering Business Management, 12, 1-13. http://dx.doi.org/10.1177/1847979020947236

Almutawa, Z., Muenjohn, N., \& Zhang, J. (2016). The effect of human resource management system on employees' commitment: The mediating role of the AMO model. The Journal of Developing Areas, 50(6), 17-29. http://dx.doi. org/10.1353/jda.2016.0147

Amah, E., \& Ahiauzu, A. (2013). Employee involvement and organizational effectiveness. Journal of Management Development, 32(7), 661-674. http:// dx.doi.org/10.1108/JMD-09-2010-0064

Appelbaum, E., Bailey, T., Berg, P., \& Kalleberg, A. L. (2000). Manufacturing advantage: Why high-performance work systems pay off. London: ILR Press.

Appelbaum, S.H., \& Kamal, R. (2000). An analysis of the utilization and effectiveness of non-financial incentives in small business. Journal of Management Development, 19(9), 733-763.

Bergman, M.E. (2006). The relationship between affective and normative commitment: Review and research agenda. Journal of Organizational Behavior, 27(5), 645-663. http://dx.doi.org/10.1002/job.372

Bhatnagar, J. (2014). Mediator analysis in the management of innovation in Indian knowledge workers: The role of perceived supervisor support, psychological contract, reward and recognition and turnover intention. The International Journal of Human Resource Management, 25(10), 1395-1416. http://dx.doi.org/10.1080/09585192.2013.870312

Blau, P.M. (1964). Justice in social exchange. Sociological Inquiry, 34(2), 193-206. http://dx.doi.org/10.1111/j.1475-682X.1964.tb00583.x

Bos-Nehles, A.C., Van Riemsdijk, M.J., \& Looise, J.K. (2013). Employee perceptions of line management performance: Applying the AMO theory to explain the effectiveness of line managers' HRM implementation. Human Resource Management, 52(6), 861-877. http://dx.doi.org/10.1002/ hrm. 21578

Bouwmans, M., Runhaar, P., Wesselink, R., \& Mulder, M. (2019). Stimulating teachers' team performance through team-oriented HR practices: The roles of affective team commitment and information processing. The International Journal of Human Resource Management, 30(5), 856-878. http://dx.doi.org/ 10.1080/09585192.2017.1322626

Boxall, P., \& Purcell, J. (2011). Strategy and human resource management (3rd ed.). London, UK: Palgrave Macmillan.

Cannon, M. (2015). Employee recognition: Understanding the construct, its measurement and its relationship to employee outcomes (Doctoral thesis, Saint Mary's University, Halifax, Nova Scotia). Retrieved from http:// proquest.umi.com.library2.smu.ca/bitstream/handle/01/26418/Cannon_ Michael_PHD_2015.pdf?sequence=1\&isAllowed=y 
Chelliah, S., Sundarapandiyan, N., \& Vinoth, B. (2015). A research on employees' organisational commitment in organisations: A case of SMEs in Malaysia. International Journal of Managerial Studies and Research, 3(7), 10-18.

Cohen, J. (1988). Statistical power analysis for the behavioral sciences (2nd ed). New York: Routledge.

Demortier, A.-L., Delobbe, N., \& El Akremi, A. (2014). Opening the black box of HR practices - performance relationship: Testing a three pathways AMO model. Academy of Management Annual Meeting Proceedings, 2014(1), http:/ / dx.doi.org/10.5465/ambpp.2014.102

Department of Statistics Malaysia. (2016). Economic Census 2016. Putrajaya: Author.

Franke, G., \& Sarstedt, M. (2019). Heuristics versus statistics in discriminant validity testing: A comparison of four procedures. Internet Research, 29(3), 430-447. http:/ / dx.doi.org/10.1108/IntR-12-2017-0515

Ghosh, P., Rai, A., Chauhan, R., Baranwal, G., \& Srivastava, D. (2016). Rewards and recognition to engage private bank employees: Exploring the “obligation dimension". Management Research Review, 39(12), 1738-1751. http:/ / dx.doi.org/https:/ / doi.org/10.1108/MRR-09-2015-0219

Giauque, D., Resenterra, F., \& Siggen, M. (2010). The relationship between HRM practices and organizational commitment of knowledge workers. Facts obtained from Swiss SMEs. Human Resource Development International, 13(2), 185-205. http:/ / dx.doi.org/10.1080/13678861003703716

Grawitch, M.J., Gottschalk, M., \& Munz, D.C. (2006). The path to a healthy workplace: A critical review linking healthy workplace practices, employee well-being and organizational improvements. Consulting Psychology Journal: Practice and Research, 58(3), 129-147. http://dx.doi.org/10.1037/1065-9293. 58.3.129

Guay, F., Vallerand, R.J., \& Blanchard, C.M. (2000). On the assessment of situational intrinsic and extrinsic motivation: The situational motivation scale (SIMS). Motivation and Emotion, 24(3), 175-213. http://dx.doi. org/10.1023/A:1005614228250

Guest, D.E. (1997). Human resource management and performance: A review and research agenda. The International Journal of Human Resource Management, 8(3), 263-376. http://dx.doi.org/10.1080/095851997341630

Guest, D.E. (2011). Human resource management and performance: Still searching for some answers. Human Resource Management, 21(1), 3-13. http:// dx.doi.org/10.1111/j.1748-8583.2010.00164.x

Hair, Joe F., Ringle, C.M., \& Sarstedt, M. (2011). PLS-SEM: Indeed a silver bullet. Journal of Marketing Theory and Practice, 19(2), 139-152. http://dx.doi. org/10.2753/MTP1069-6679190202

Hair, Joseph F., Black, W.C., Babin, B.J., \& Anderson, R.E. (2013). Multivariate data analysis. New York, NY: Pearson Education Limited. 
Hair, Joseph F., Hult, G.T.M., Ringle, C.M., \& Sarstedt, M. (2017). A primer on partial least squares structural equation modeling (PLS-SEM). Thousand Oaks, CA: Sage Publications, Inc.

Hair, Joseph F., Sarstedt, M., Ringle, C.M., \& Gudergan, S.P. (2018). Advanced issues in partial least squares structural equation modeling. Thousand Oaks, CA: Sage Publications, Inc.

Henseler, J., Ringle, C.M., \& Sarstedt, M. (2015). A new criterion for assessing discriminant validity in variance-based structural equation modeling. Journal of the Academy of Marketing Science, 43(August), 115-135. http:// dx.doi.org/10.1007/s11747-014-0403-8

Henseler, J., Ringle, C.M., \& Sinkovics, R.R. (2009). The use of partial least squares path modeling in international marketing. Advances in International Marketing (Advances in International Marketing), 20, 277-319. http://dx.doi. org/10.1108/S1474-7979(2009)0000020014

Hooi, L.W., \& Ngui, K.S. (2014) Enhancing organizational performance of Malaysian SMEs: The role of HRM and organizational learning capability. International Journal of Manpower, 35, 973-995. http://dx.doi.org/10.1108/ IJM-04-2012-0059.

Islam, T., Khan, S.R., Norulkamar, U., Ahmad, U.N.U., \& Ahmed, I. (2013). Organizational learning culture and leader-member exchange quality: The way to enhance organizational commitment and reduce turnover intentions. The Learning Organisation, 20(4/5), 322-337. http://dx.doi. org/10.1108/TLO-12-2012-0079

Jiang, K., Lepak, D.P., Han, K., Hong, Y., Kim, A., \& Winkler, A.-L. (2012). Clarifying the construct of human resource systems: Relating human resource management to employee performance. Human Resource Management Review, 22(2), 73-85. http://dx.doi.org/10.1016/j.hrmr.2011.11.005

Johar, E.R., Nor, N.M., Hassan, R., \& Musa, R. (2019). Examining the effect of motivation on the influence of human resource practices and normative commitment among SMEs in Selangor. Asia-Pacific Management Accounting Journal, 14(1), 179-200.

Jones, D.C., Kalmi, P., \& Kauhanen, A. (2010). How does employee involvement stack up? The effects of human resource management policies on performance in a retail firm. Industrial Relations, 49(1), 1-22. http://dx.doi. org/10.1111/j.1468-232X.2009.00584.x

Kim, K.Y., Pathak, S., \& Werner, S. (2015). When do international human capital enhancing practices benefit the bottom line? An ability, motivation, and opportunity perspective. Journal of International Business Studies, 46(7), 784805. http://dx.doi.org/10.1057/jibs.2015.10

Kline, R.B. (2016). Principles and practice of structural equation modeling. New York, NY: Guilford Press.

Knies, E., \& Leisink, P. (2014). Linking people management and extra-role behaviour: Results of a longitudinal study. Human Resource Management Journal, 24(1), 57-76. http:/ / dx.doi.org/10.1111/1748-8583.12023 
Kock, N., \& Lynn, G.S. (2012). Lateral collinearity and misleading results in variance-based SEM: An illustration and recommendations. Journal of the Association for Information Systems, 13(7), 546-580. http://dx.doi. org/10.17705/1jais.00302

Kroon, B., Van De Voorde, K., \& Timmers, J. (2013). High performance work practices in small firms: A resource-poverty and strategic decisionmaking perspective. Small Business Economics, 41(1), 71-91. http://dx.doi. org/10.1007/s11187-012-9425-0

Lee, C.-C., \& Chen, C.-J. (2013). The Relationship between Employee Commitment and Job Attitude and Its Effect on Service Quality in the Tourism Industry. American Journal of Industrial and Business Management, 3, 196-208.

Li, N., Jung, G.Y., \& Kim, H.H. (2020). A study on the effect of transformation leadership on the job performance of employees by AMO model. Journal of the Korea Convergence Society, 11(1), 41-50. http://dx.doi.org/10.15207/ JKCS.2020.11.1.041

Marin-Garcia, J.A., \& Tomas, J.M. (2016). Deconstructing AMO framework: A systematic review. Intagible Capital, 12(4), 1040-1087. http://dx.doi. org/10.3926/ic. 838

Merkle, D.M. (2008). Nonresponse bias. In P.J. Lavrakas (Ed.), Encyclopedia of survey research methods. Thousand Oaks, CA: Sage Publications, Inc.

Meyer, J.P., \& Allen, N.J. (1991). A three-component conceptualization of organizational commitment. Human Resource Management Review, 1(1), 6189. http://dx.doi.org/10.1016/1053-4822(91)90011-Z

Mulolli, E., Islami, X., \& Skenderi, N. (2015). Human resource management practices and SMEs performance: Study based in Kosovo. International Review of Management and Business Research, 4(4), 1171-1180.

Mowday, R.T., Steers, R.M., \& Porter, L.W. (1979). The measurement of organizational commitment. Journal of Vocational Behavior, 14(2), 224-247. http:// dx.doi.org/10.1016/0001-8791(79)90072-1

National SME Development Council. (2012). SME Master Plan 2012-2020. Kuala Lumpur: Author. Retrieved from https://smeinfo.com.my/policyregulation/sme-masterplan

National SME Development Council. (2017). SME Annual Report 2017/2018. Kuala Lumpur: Author.

Noe, R.A., Hollenbeck, J.R., Gerhart, B., \& Wright, P.M. (2010). Human resource management: Gaining a competitive advantage. New York, NY: McGraw-Hill/ Irwin.

Nor, N.M., \& Abdullah, F. (2020). The relationships between ability, motivation and opportunity (AMO) model of high-performance work practices (HPWP) and organizational performance on millennials in MARA Headquarters, Kuala Lumpur: Mediated by job embeddedness. International Journal of Academic Research in Business and Social Sciences, 10(13), 62-72. 
Obeidat, S.M., Bray, M., \& Mitchell, R. (2010). Examining the link between high performance human resource practices (HPHRP) and organisational performance: Evidence from the Jordanian manufacturing and financial sectors. Anzam 2010. Retrieved from https://www.anzam.org/wpcontent/uploads/pdf-manager/809_ANZAM2010-293.PDF

Obeidat, S.M., Mitchell, R., \& Bray, M. (2016). The link between high performance work practices and organizational performance: Empirically validating the conceptualization of HPWP according to the AMO model. Employee Relations, 38(4), 578-595. http://dx.doi.org/10.1108/ER-08-20150163

Osa, I.G., \& Amos, I.O. (2014). The impact of organizational commitment on employees productivity: A case study of Nigeria Brewery, PLC. International Journal of Research in Business Management, 2(9), 107-122.

Paré, G., \& Tremblay, M. (2000). The measurement and antecedents of turnover intentions among IT professionals (CIRANO Working Papers 2000s33). Montreal, Canada: CIRANO. Retrieved from https://core.ac.uk/ download/pdf/7315378.pdf

Podsakoff, P.M., MacKenzie, S.B., Lee, J.-Y., \& Podsakoff, N.P. (2003). Common method biases in behavioral research: A critical review of the literature and recommended remedies. Journal of Applied Psychology, 88(5), 879-903. https:// doi.org/10.1037/0021-9010.88.5.879

Prabusankar, R. (2015). Impact of human resource management practices on organizational commitment in small scale industries in Coimbatore District. International Journal of Business and Administration Research Review, 2(11), 164-168.

Randstad. (2019). Malaysia 2019. Employer Brand Research. Retrieved from https:/ / www.mdbc.com.my/wp-content/uploads/2019/08/Randstad-Malaysia2019-Employer-Brand-Research.pdf

Rizzo, J.R., House, R.J., \& Lirtzman, S.I. (1970). Role conflict and ambiguity in complex organizations. Administrative Science Quarterly, 15(2), 150-163. http:/ / dx.doi.org/10.2307/2391486

Saks, A.M. (2006). Antecedents and consequences of employee engagement. Journal of Managerial Psychology, 21(7), 600-619. http:/ /dx.doi.org/10.1108/ 02683940610690169

Schimansky, S. (2014). The effect of a high-commitment work system on innovative behavior of employees. Paper presented at the 3rd IBA Bachelor Thesis Conference, 3 July, Enschede, the Netherlands. Retrieved from https:// essay.utwente.nl/65249/1/Schimansky_BA_MB.pdf

Schyns, B., \& von Collani, G. (2002). A new occupational self-efficacy scale and its relation to personality constructs and organizational variables. European Journal of Work and Organizational Psychology, 11(2), 219-241. http:/ / dx.doi. org/10.1080/13594320244000148

Shin, D., \& Konrad, A.M. (2014). Causality between high-performance work 
systems and organizational performance. Journal of Management, 43(4), 973997. http://dx.doi.org/10.1177/0149206314544746

SME Corporation Malaysia. (2018). Annual Report 2017. Kuala Lumpur: Author.

Subramaniam, C., Shamsudin, F.M., \& Ibrahim, H. (2011). Linking human resource practices and organisational performance: Evidence from small and medium organisations in Malaysia. Jurnal Pengurusan, 32, 27-37.

Voorhees, C.M., Brady, M.K., Calantone, R., \& Ramirez, E. (2016). Discriminant validity testing in marketing: An analysis, causes for concern, and proposed remedies. Journal of the Academy of Marketing Science, 44(1), 119-134. http://dx.doi.org/10.1007/s11747-015-0455-4

Wayne, S.J., Shore, L.M., Bommer, W.H., \& Tetrick, L.E. (2002). The role of fair treatment and rewards in perceptions of organizational support and leader-member exchange. Journal of Applied Psychology, 87(3), 590-598. http://dx.doi.org/10.1037/0021-9010.87.3.590

Williams, B.M. (1978). A sampler on sampling. New York, NY: John Wiley \& Sons.

Wongboonsin, K., Dejprasertsri, P., Krabuanrat, T., Roongrerngsuke, S., Srivannaboon, S., \& Phiromswad, P. (2018). Sustaining employees through coworker and supervisor support: Evidence from Thailand. Asian Journal of Business and Accounting, 11(2), 187-214. http://dx.doi.org/10.22452/ajba. vol11no2.6

$\mathrm{Yu}$, J., \& Cooper, H. (1983). A quantitative review of research design effects on response rates to questionnaires. Journal of Marketing Research, 20(1), 36-44. http://dx.doi.org/10.2307/3151410

Zakaria, N., Zainal, S.R.M., \& Nasurdin, A.M. (2011). Investigating the role of human resource management practices on the performance of SME: A conceptual framework. Journal of Global Management, 3(1), 74-92.

Zopiatis, A., Constanti, P., \& Theocharous, A.L. (2014). Job involvement, commitment, satisfaction and turnover: Evidence from hotel employees in Cyprus. Tourism Management, 41(April), 129-140. http://dx.doi. org/10.1016/j.tourman.2013.09.013 


\section{Appendix}

Table A1: Employee Involvement - Items, Mean Score and Standard Deviation

Items

Code Mean Standard

Deviation

In general, how much influence do you have

E1

5.38

0.976

on the tasks that you do?

In general, how much influence do you have

E2

5.36

0.943

on the pace at which you work?

In general how much influence do you have

E3

5.40

0.912

in order to carry out tasks?

In general, how much influence do you have

E4

5.45

0.890

in the way you do your work?

In general, how much influence do you have

E5

5.44

0.971

on starting time/finishing workday?

How good are managers to tell staff about the

E6

5.19

1.289

changes in how the organisation operates?

How good are managers to inform employees

E7

about changes in staffing?

How good are managers to inform staff about

E8

5.13

1.208

changes in the way you do your job?

How good are managers to inform staff on

E9

4.79

1.433

financial matters?

How good are managers to seek the views of

E10 4.97

1.247

employees/workers representatives?

How good are managers to respond to

E11 4.95

suggestions from employees/workers

representatives?

How good are managers to allow employees /

E12

4.85

workers representatives to influence the

final decision?

How satisfied are you with the amount of

E13

4.92

1.426 
Table A2: Employee Recognition - Items, Mean Score and Standard Deviation Items

\begin{tabular}{|c|c|c|}
\hline Code & Mean & $\begin{array}{l}\text { Standard } \\
\text { Deviation }\end{array}$ \\
\hline
\end{tabular}

$\begin{array}{llll}\text { When I do a good job, supervisor/manager } & \text { RE1 } & 5.00 & 1.274\end{array}$ tells me so.

I never get compliments from those above me RE2 $\quad 4.63$ for a job well done.

My manager/supervisor often acknowledges RE3 4.85 when I have done a good job.

No one ever acknowledges my achievements

RE4 $\quad 5.06 \quad 0.986$

My manager/supervisor only notices my

RE5 $\quad 5.05$ 1.010 mistakes, and not my achievements.

Table A3: Ability - Items, Mean Score and Standard Deviation

\begin{tabular}{lccc}
\hline Items & Code & Mean & $\begin{array}{c}\text { Standard } \\
\text { Deviation }\end{array}$ \\
\hline $\begin{array}{l}\text { As far as my job is concerned I am a self- } \\
\text { reliant person. }\end{array}$ & A1 & 5.41 & 1.040 \\
$\begin{array}{l}\text { If I try hard enough, I can always manage to } \\
\text { solve difficult problems in my work. }\end{array}$ & A2 & 5.74 & 0.869 \\
$\begin{array}{l}\text { I can remain calm when I have difficulties in } \\
\text { my job, because I can rely on my abilities. }\end{array}$ & A3 & 5.55 & 0.906 \\
$\begin{array}{l}\text { Thanks to my resourcefulness, I know how } \\
\text { to deal with unforeseen situations in my job. }\end{array}$ & A4 & 5.44 & 0.951 \\
$\begin{array}{l}\text { If I have trouble at work, I can usually think } \\
\text { of something to do. }\end{array}$ & A5 & 5.49 & 1.016 \\
$\begin{array}{l}\text { No matter what happens to my job, I'm usually } \\
\text { able to handle it. }\end{array}$ & A6 & 5.57 & 0.861 \\
$\begin{array}{l}\text { I am confident that I can deal efficiently with } \\
\text { unexpected events in my job. }\end{array}$ & A7 & 5.51 & 0.938 \\
\hline
\end{tabular}


Table A4: Motivation - Items, Mean Score and Standard Deviation

Items

$\begin{array}{ccc}\text { Code } & \text { Mean } & \begin{array}{r}\text { Standard } \\ \text { Deviation }\end{array} \\ \text { M1 } & 5.45 & 1.215 \\ \text { M2 } & 5.37 & 1.301 \\ \text { M3 } & 4.03 & 1.724 \\ \text { M4 } & 5.43 & 1.175 \\ \text { M5 } & 5.14 & 1.298 \\ \text { M6 } & 4.91 & 1.344 \\ \text { M7 } & 5.31 & 1.311 \\ & & \end{array}$

Table A5: Opportunity - Items, Mean Score and Standard Deviation

\begin{tabular}{|c|c|c|c|}
\hline Items & Code & Mean & $\begin{array}{l}\text { Standard } \\
\text { Deviation }\end{array}$ \\
\hline
\end{tabular}

I can do the same thing, regardless of the

$\mathrm{O} 1 \quad 5.27 \quad 1.178$
group I am with.

I have enough time to finish my job.

$\mathrm{O} 24.93$

I feel confident about how much authority

$\mathrm{O} 3 \quad 5.05$

I have.

I know exactly what is expected of me.

$\mathrm{O} 4$

I have to do things that need to be done

differently.

I get the right support from my company

O6 to do my job well.

I receive assignments that are part of my 
Table A6: Normative Commitment - Items, Mean Score and Standard Deviation Items Code Mean Standard Deviation

I have no obligation to remain with my organisation.

$\begin{array}{llll}\text { Even if it were to my advantage, I do not feel } \quad \text { NC2 } & 4.40 & 1.475\end{array}$ it would be right to leave.

If I had left this organisation now, I would NC3 $\quad 4.25$ 1.748 feel guilty.

This organisation deserves my loyalty. NC4 4.64 1.674

Right now, I would not leave my organisation $\quad$ NC5 $\quad 4.71 \quad 1.564$ because of my sense of obligation to it.

I owe a lot to this organisation.

NC6 $\quad 4.52$ 1.608 
